\title{
Disrupted Airports and Disruptive Technology: A Recipe for Mutual Advantage?
}

\author{
Padraic Regan \\ Correspondence: School of Business, Trinity College, Dublin, Ireland
}

Received: November 2, $2014 \quad$ Accepted: December 10, $2014 \quad$ Online Published: December 18, 2014
doi:10.11114/bms.v1i1.615
URL: http://dx.doi.org/10.11114/bms.v1i1.615

\begin{abstract}
Much work has been undertaken showing that executive air travel can have stress-related consequences. As greater use of Information and Communication Technologies (ICT) has been put forward as a substitute for air travel, then such activity would appear to be a realistic strategy to relieve air travel-related stressors. Although one projection estimated the potential substitution effect at $70 \%$, to date however, empirical studies have come up with much more modest numbers. This paper aims to update the literature on two relatively recent developments in respect of these substitution effects, viz. increased congestion at European airports and advances in mobile technologies. The results suggest that the combined impact of these developments will result in more business communications being undertaken in relatively stress-free environments thus providing potential benefits for both sectors.
\end{abstract}

Keywords: airport capacity, mobile technology, congestion, business air travel, stress

\section{Introduction}

One of the many challenges that business executives must contend with is the stress associated with air travel (Tahvanainen et al., 2005). Greater use of information communications technology (ICT), particularly in the form of videoconferencing, has been put forward as having the potential to reduce or replace business air travel and hence its related stress (Bender and Stephenson, 1998; Starr and Currie, 2009).

Termed "major enablers of the globalisation of business" by Wickham and Vecchi (2009: 245), ICT and executive air travel have had an uneasy relationship in the academic literature. On the one hand, they have been seen as substitute for one another (e.g. Roy \& Filiatrault, 1998) whilst on the other, they are considered to act in a complementary fashion with increases in one type of communication leading to an increase in the other (e.g. Denstadli et al, 2013). Moreover, ICT itself is not without its adverse health potential as increased use of ICT can result in increased pain (Goldfinch et al, 2011).

Whilst earlier predictions of up to 70\% substitution between business air travel and ICT (Lianand Denstadli, 2004) have never materialised, recent developments in both of these areas, i.e. increased congestion in European airports and increased sophistication of mobile technology, may well serve to underpin this prediction and, in so doing, provide benefits to both. This paper explores the potential impact of these developments, firstly by examining the links between stress and air travel, then by updating the literature with respect to the substitution potential of these developments and finally, deriving some practical conclusions.

\section{Stress and Air Travel for the Executive}

\subsection{Business Air Travel and its Health Implications}

Aviation is one of the world's largest industries; last year, over 1000 commercial airlines generated revenues of US\$600 billion carrying some 3 billion passengers and 46 million tonnes of cargo (IATA, 2011). Although business travellers are increasingly opting for cheaper fares on low cost carriers (Martinez-Garcia et al, 2012; Neal and Kassens-Noor, 2011), the importance of the three main types of business travel, i.e. conferences, incentive travel, and exhibitions and trade shows (Dawson, 1994), to airlines is significant with one study suggesting that premium tickets were purchased by some 50\% of the short-haul business air travellers in UK and over 65\% in Continental Europe (Mason, 2005).

International business travel offers many benefits including personal growth (Starr \& Currie, 2009), the development of a global mindset (Oddou et al, 2000), enhanced well-being (Demel \& Mayerhofer, 2010), escape from routine family responsibilities (Westman et al, 2008), and stimulation derived from new environments (Mayerhofer et al., 2004). 
Indeed, a carefully designed international travel programme for executives can constitute a "strategic management development tool" (Oddou et al, 2000: 159).

Increasingly, however, studies are identifying the downsides of business air travel including strained social relationships (Westman et al, 2009), jet lag and poor health (DeFrank et al, 2000), more serious conditions such as alcoholism and stress (Shaffer et al, 2012), and even the risk of venous thrombosis (Schreijer et al, 2010).

DeFrank and colleagues define the stress associated with long-distance travel as "the perceptual, emotional, behavioral, and physical responses made by an individual to the various problems faced during one or more of the phases of travel" with the three different phases identified as pre-trip, trip, and post-trip, (2000: 59). Pre-trip stressors include trip planning and ensuring that work and family matters are attended to before the trip takes place; when applied to planning a holiday, de Bloom and colleagues term this "working-ahead stress" (2010: 198). Trip stressors include aviation-related factors with DeFrank and colleagues (2000) reporting one survey that indicated over 50\% of air travellers found flight delays a source of anxiety whilst $30 \%$ experienced anxiety associated with baggage reclaim. Post-trip stressors (called "catch-up stress" by de Bloom and colleagues (2010: 213) in a post-holiday scenario) relate to job and family issues that have been missed while away. Nor is it just the travelling executive that experiences stress as their absence may cause stress to work colleagues and family members (Starr and Currie, 2009).

In a survey of thirty-five American, Israeli and Swedish business travellers, Westman (2004) identified four trip phases, viz. (i) pretrip, (ii) journey, (iii) stay, and (iv) posttrip, and found that different coping strategies were deployed for each phase. Nor does taking work with them on their trip necessarily reduce stress as the combination of travel and work can erode the notion of 'me-time' and render work "boundaryless" (Gustafson, 2012: 203).

Using the same definition of business travel stress as DeFrank and colleagues (2000), Ivancevich and colleagues (2003) put forward a framework aimed at assisting executives to better understand and manage travel stressors. This framework is premised on the person-environment (P-E) fit model in which stress arises as a result of a misalignment between the person and the environment.

\subsection{Substitution of Air Travel by ICT}

For over half a century, videoconferencing has been touted as a substitute for air travel but the level identified in empirical studies has been modest as such forecasts "continue to be deferred" (Haynes, 2010: 547). In their investigation into Canadian business air travel and the impact of videoconferencing, Roy and Filiatrault (1998) concluded that increased penetration and utilization rates of the technology would substitute for air travel in the future with the rate in 2000 estimated at somewhere between $4 \%$ and 9\%. In 2004, Denstadli estimated substitution rates for the Norwegian market of $2.5 \%$ to $3.5 \%$. Lian and Denstadli (2004: 113/114) reported a "slightly higher degree of realism with respect to the potential of future business travel being substituted by VC" (videoconferencing) when comparing two surveys of Norwegian businesses undertaken in 1998 and 2003. Lu and Peeta (2009) examined intra-company business air travel and videoconferencing on a bi-directional basis in the Taiwanese technology sector and confirmed stronger support for the latter acting as a substitute for the former than vice versa.

Four possibilities have been identified in the ICT / travel relationship literature (Denstadli et al, 2013), viz. (i) substitution, whereby a virtual meeting of one form or another replaces a physical, face-to-face meeting; (ii) complementarity, when one type of communication, e.g. an email, generates the use of another, e.g. an air trip; (iii) modification, where the use of one form of communication changes the use of another, e.g. a personal visit results in mobile phones being used to continue / progress the business relationship, and (iv) neutrality, in which the use of air travel operates independently of the use of ICT and vice versa.

Although the substitution effect has achieved modest volumes to date, two developments in particular are poised to bring about a more substantial swing in favour of ICT, increased congestion at European airports and advances in technology.

\section{The Case for Increased Substitution}

\subsection{Capacity Issues and European Airports}

"All forecasts indicate that Europe will progressively run out of capacity at its hub airports between now and 2030" (McNamara, 2012: 3).

Traditionally seen as somewhat passive players in the aviation sector, European airports have undergone a major transformation over the past two decades and now constitute "complex multiproduct, multiservice enterprises" (Appold \& Kasarda, 2011: 91) and are among "the most complex interdependent operational environments" (EC, 2011: 5). The trend towards commercialisation came about as a result of demands for greater efficiency and greater investment (Castro \& Lohmann, 2014), with governments in many instances deciding that privatisation was the best option for 
achieving same (Czinkota \& Ronkainen, 2005; Frank, 2011; Graham, 2011).

European airports have become an increasing important part of the aviation chain, both in terms of passenger and cargo connectivity within the European Union and with the rest of the world (Murel \& O'Connell, 2011); they are a key component of the proposed 'Single European Sky' (EC, 2011) and of the International Air Transport Association's 'Vision 2050' (IATA, 2011).

However, as European airports approach capacity, increased delays are inevitable (Wilken et al, 2011) and increased delays cause considerable frustration among business travellers. A study by the U.S. Travel Association in 2008 indicated that delays in the air transport system resulted in an estimated 41 million trips being avoided, costing the U.S. economy in excess of $\$ 26$ billion (Air Travel Survey, 2008).

The most recent study into European airport capacity paints a somewhat gloomy picture in terms of the impact on the air traveller (Eurocontrol, 2013). In this study, four scenarios covering some 2000 airports are compiled to look ahead to 2035 and 2050 with each scenario having different assumptions relating to economic growth, aviation fuel prices, airline load factors, direct versus indirect passenger flows, etc. The four scenarios are: A. Global Growth, based on strong growth; C. Regulated Growth, the most likely scenario; C'. Happy Localism, similar to C but with Europe closing boundaries; and D. Fragmenting World, more friction and reduced globalisation. By simulating two busy Summer months under scenario $C$, more than 20 airports are projected to be operating at $80 \%$ or more of capacity for 6 or more hours per day (at 3 or more hours per day, the number of congested airports rises to 30) by 2035 compared to just three in Summer 2012. Based on current airport capacity plans, 1.9 million flights (12\% of total demand) cannot be accommodated by 2035 ; this is equivalent to some 120 million passengers on return trips and would require nine new runways to facilitate. The impact on airport delays is even more dramatic, increasing from one minute per flight in 2012 to five or six minutes in 2035 .

Even by combining seven different - and in some cases highly political and expensive-methods to alleviate the congestion envisaged, less than half of the anticipated 'unaccommodated' demand is catered for. Nor is it always the case that investments in airport capacity, particularly given the highly capital-intensive nature of airport investment and the restricted lending potential of the banking sector, result in the creation of economic value. In a study by Vogel (2011) of ten privatised European airport companies covering the period 2003 - 2009, the value-added for most was negative. One suggestion aimed at increasing the financial situation at airports is the provision of dedicated low-cost terminals (Njoya \& Niemeier, 2011).

\subsection{Developments in ICT}

Since the arrival of videoconferencing as a potential replacement for business air travel in the 1960s, developments in technology have advanced substantially (Beaverstock et al, 2010). From the introduction of desktop systems which removed videoconferencing out of purpose-built conference rooms to the widespread availability of mobile devices (predominantly mobile phones and tablets), the opportunities for executives to engage in business communication whenever and where ever they chose has never been greater (Denstadli et al, 2013).

The rate at which mobile devices are replacing 'fixed' devices is dramatic. According to one estimate, PC sales reached 350 million units in 2012 compared with 1.7 billion mobile units. Today, some 3.2 billion mobile devices are in use compared to 1.6 billion PC units with smartphones (and latterly smart watches) bridging the gap between the technology and the mobility; by 2015 the number of smartphones is projected to equal the number of literate adults (Evans, 2013).

\section{Conclusions and Implications}

Face-to-face meetings and personal presence will always occupy a central position in building business relationships, particularly in a multi-cultural, globalised environment (DeFrank et al, 2000). Nevertheless, the much-cited but never-achieved potential for ICT to act as a substitute for business air travel and hence reduce air travel-related stress levels has been boosted by the combined effects of two independent developments. The first of these is the accelerating exhaustion of capacity at Europe's larger airports. The second is the rapid deployment of advanced technological solutions for distance-based business communications.

These developments have the potential to assist business travellers and their employers to manage the stress associated with air travel whilst simultaneously alleviating pressure on congested airports No longer do executives have to face the choice of either grappling with air travel stressors or reserving an ICT-equipped conference room in order to conduct business meetings, in future they can conduct their business where they choose.

\section{References}

Air Travel Survey. (2008). Prepared by U. S. Travel Association (available at: http://www.ustravel.org/research). 
Appold, S. J., \& Kasarda, J. D. (2011). Seeding growth at airports and airport cities: Insights from the two-sided market literature. Research in Transportation Business \& Management, 1, 91-100. http://dx.doi.org/10.1016/j.rtbm.2011.06.011

Beaverstock, J. V., Derudder, B., Faulconbridge, J. R., \& Witlox, F. (2010). International Business Travel and the Global Economy: Setting the Context. In: Beaverstock, J.V. Derudder, B. Faulconbridge, J.R., Witlox, F. (Eds.), International Business Travel in the Global Economy, Farnham, Ashgate,1-7.

Bender, A. R., \& Stephenson, F. J. (1998). Contemporary issues affecting the demand for business air travel in the United States. Journal of Air Transport Management,106, 371-376.

Castro, R., \& Lohmann, G. (2014). Airport branding: Content analysis of vision statements. Research in Transportation Business and Management. http://dx.doi.org/10.1016/j.rtbm.2014.01.001

Challenges of Growth (2013).Eurocontrol (available from http://www.eurocontrol.int/articles/challenges-growth).

Czinkota, M. R., \& Ronkainen, I. A. (2005). A forecast of globalization, international business and trade: report from a Delphi study. Journal of World Business, 40, 111-123. http://dx.doi.org/10.1016/j.jwb.2005.02.006

Dawson, R. (1994).Business Travel. Pitman Publishing Ltd., London.

De Bloom, J., Geurts, S. A. E., Taris, T. W., Sonnentag, S., de Weerth, C., \& Kompier, M. A. J. (2010). Effects of Vacation from Work on Health and Well-being: Lots of fun, quickly gone. Work \& Stress,24(2), 196-216. http://dx.doi.org/10.1080/02678373.2010.493385

DeFrank, R. S., Robert, K. R., \& Ivancevich, J. M. (2000). Executive Travel Stress: Perils of the Road Warrior. Academy of Management Executive, 14(2), 58-71.

Demel, B., \& Mayerhofer, H. (2010). Frequent business travelers across Europe: Career Aspirations and Implications. Thunderbird International Business Review, 52, 301-311. http://dx.doi.org/10.1002/tie.20352

Denstadli, J. M. (2004). Impacts of Videoconferencing on Business Travel: The Norwegian Experience. Journal of Air Transport Management, 4, 99-109.

Denstadli, J. M., Gripsrud, M., Hjorthol, R., \& Julsrud, T. E. (2013). Videoconferencing and business air travel: Do new technologies produce new interaction patterns? Transportation Research Part C,29, 1-13. http://dx.doi.org/10.1016/j.trc.2012.12.009

European Commission. (2011). Airport policy in the European Union - addressing capacity and quality to promote growth, connectivity and sustainable mobility. Available at: http://ec.europa.eu/transport/modes/air/airports/doc/2011-airport-package-communication_en.pdf.

Evans, B. (2013). The Future is Mobile (available at: http://ben-evans.com/benedictevans/2013/5/17/mobile-is-eating-the-world)

Frank, L. (2011). Business Models for Airports in a Competitive Environment.One sky, different stories.Research in Transportation Business \& Management, 1, 25-35.

Goldfinch, S., Gauld, R., \& Baldwin, N. (2011). Information and Communications Technology use, e-government, Pain and Stress amongst Public Servants. New Technology, Work \& Employment. 26(1), 39-53. http://dx.doi.org/10.1111/j.1468-005X.2010.00256.x

Graham, A. (2011). The objectives and outcomes of airport privatisation. Research in Transportation Business \& Management, 1, 3-14.

Gustafson, P. (2012). Travel time and working time: What business travellers do when theytravel, and why. Time \& Society, 21(2) 203-222. http://dx.doi.org/10.1177/0961463X12444057

Haynes, P., (2010). Information and Communication Technology and International Business Travel: Mobility allies? Mobilities, 5 (4), 547-564. http://dx.doi.org/10.1080/17450101.2010.510337

IATA (International Air Transport Association). 2011. Vision 2050. Available from: http://www.iata.org/pressroom/facts_figures/Documents/vision-2050.pdf.

Ivancevich, J. M., Konopaske, R., \& DeFrank, R. S. (2003). Business travel stress: A model, propositions and managerial implications. Work and Stress, 17(2), 138-157.http://dx.doi.org/10.1080/0267837031000153572

Lian, J. I., \& Denstadli, J. M. (2004). Norwegian business air travel-segments and trends.Journal of Air Transport Management. 10, 109-118. http://dx.doi.org/10.1016/j.jairtraman.2003.08.001

Lu, J. L., \& Peeta, S. (2009).Analysis of the factors that influence the relationship between Business Air Travel and 
Videoconferencing. Transportation Research Part A,43, 709-721.http://dx.doi.org/10.1016/j.tra.2009.07.001

Mason, K. J. (2005). Observations of Fundamental Changes in the Demand for Aviation Services.Journal of Air Transport Management. 11, 19-25. http://dx.doi.org/10.1016/j.jairtraman.2004.11.007

Mayerhofer, H., Hartmann, L. C., Michelitsch-Riedl, G., \& Kollinger, I. (2004). Flexpatriate assignments: a neglected issue in global staffing. The International Journal of Human Resource Management,15, 8, 1371-1389. http://dx.doi.org/10.1080/0958519042000257986

McNamara, S. (2012). Airport Capacity at EU hub airports: Why European Regulators have missed an opportunity... European Regional Airline Association. Available at:

https://www.eraa.org/library/position-papers/cat_view/86-issues/89-airports-a-ground-ops/279-airport-capacity

Murel, M., \& O'Connell, J. F. (2011). Potential for Abu Dhabi, Doha and Dubai Airports to reach their traffic objectives. Research in Transportation Business \& Management, 1, 36-46. http://dx.doi.org/10.1016/j.rtbm.2011.06.004

Neal Z. P., \& Kassens-Noor, Z. (2011). The business passenger niche: Comparing legacy carriers and southwest during a national recession. Journal of Air Transport Management, 17, 231-232. http://dx.doi.org/10.1016/j.jairtraman.2010.09.001

Njoya, E. T., \& Niemeier, H. M. (2011). Do dedicated low-cost passenger terminals create competitive advantages for airports? Research in Transportation Business \& Management, 1, 55-61. http://dx.doi.org/10.1016/j.rtbm.2011.06.005

Oddou, G., Mendenhal, M. E., \& Bonner, R. J. (2000). Leveraging Travel as a tool for GlobalLeadershipDevelopment. Human Resource Management, 39, (2, 3), 159-172.

Roy, J., \& Filiatrault, P. (1998). The impact of new business practices and information technologies on business air travel demand. Journal of Air Transport Management,4, 77-86. http://dx.doi.org/10.1016/S0969-6997(98)00009-X

Schreijer, A. J. M., Hoylaerts, M. F., Meijers, J. C. M., Lijnen, H. R., Middeldorp, S., Buller, H. R., Reitsma, P. H., Rosendaal, F. R. \& Cannegieter, S. C. (2010). Explanations for Coagulation Activation after Air Travel. Journal of Thrombosis and Haemostasis, 8, 971-978.

Shaffer, M. A., Kraimer, M. L., Chen, Y. P., \& Bolino, M. C. (2012). Choices, Challenges, and Career Consequences of Global Work Experiences: A Review and Future Agenda. Journal of Management, 38(4), 1282-1327. http://dx.doi.org/10.1177/0149206312441834

Tahvanainen, M., Welch, D., \& Worm, V. (2005).Implications of Short-term International Assignments. European Management Journal, 23, 663-673. http://dx.doi.org/10.1016/j.emj.2005.10.011

Vogel, H. A. (2011). Do privatized airports add financial value? Research in Transportation Business \& Management,1, $15-24$.

Westman, M. (2004). Strategies for Coping with Business Trips: A Qualitative Exploratory Study. International Journal of Stress Management,11(2), 167-176. http://dx.doi.org/10.1037/1072-5245.11.2.167

Westman, M., Etzion, D., \& Gattenio, E. (2008). International business travels and the work-family interface: A longitudinal study. Journal of Occupational and Organizational Psychology, 81, 459-480. http://dx.doi.org/10.1348/096317908X310265

Westman, M., Etzion, D., \& Chen, S. (2009). Crossover of positive experiences from business travelers to their spouses. Journal of Managerial Psychology, 24, 269-284.http://dx.doi.org/10.1108/02683940910939340

Wickham, J., \& Vecchi, A. (2009). The importance of Business Travel for Industrial Clusters - Making Sense of Nomadic Workers. Geografiska Annaler: Series B, Human Geography, 91(3), 245-255.

Wilken, D., Berster, P., \& Gelhausen, M.C. (2011). New empirical evidence on airport capacity utilisation: Relationships between hourly and annual air traffic volumes. Research in Transportation Business \& Management, $1,118-127$.

\section{(cc) BY}

This work is licensed under a Creative Commons Attribution 3.0 License. 